\title{
Effect of subsurface amendments and drip irrigation on tomato growth
}

\author{
A. M. Al-Omran ${ }^{1}$, A. S. Sheta ${ }^{1}$, A. M. Falatah ${ }^{1} \&$ A. R. Al-Harbi ${ }^{2}$ \\ ${ }^{I}$ Department of Soil Science, College of Food and Agricultural Sciences, \\ King Saud University, Saudi Arabia \\ ${ }^{2}$ Department of Plant Production, College of Food and Agricultural \\ Sciences, King Saud University, Saudia Arabia
}

\begin{abstract}
The management that increases yield and reduce excessive amount of water is a priority for agriculture development in arid and semi-arid regions. This research investigated the effectiveness of previously subsurface placement $(25 \mathrm{~cm})$ of the clay deposits and drip irrigation on tomato yield, water use efficiency (WUE), soil moisture and salt distribution in the root zone. A calcareous sandy soil had a subsurface amendments and surface and subsurface drip irrigation applied for one year and planted with squash crop prior to seedling tomato. The field experimental site, and randomization, and consequently location of each treatment, replication was the same for the tomato experiment. The clay deposits were collected from western (Khulays) and central (Dhruma and Rawdat) regions of Saudi Arabia. Surface and subsurface drip irrigation were used at rates ranging from $234 \mathrm{~mm}$ (T1) to $564.5 \mathrm{~mm}$ (T4). The results clearly reveal that nutrients levels in all the experimental plots were quite variable depending on the amendments type, and rate of application, and the irrigation systems. Results show that tomato fruit yield and WUE were significantly affected by amendments rates and type and also by irrigation amounts and system. The soil moisture contents of subsurface drip irrigated layer increased dramatically, while salts accumulated at the surface away from the emitters of subsurface drip irrigation.
\end{abstract}

Keywords: drip irrigation, clay deposit, tomato yield, sandy calcareous soils, water use efficiency. 


\section{Introduction}

The sustainable use of scarce water resources in Saudi Arabia is a priority for agricultural development. Therefore, practices that increase water use efficiency and reduce excessive amount of water applied to the field are important in water management. Also, adoption of modern irrigation techniques is needed to be emphasized to increase water use efficiency. Drip irrigation is the most effective way to apply directly water and nutrients to plants and not only save water but also increases yields of vegetable crops (Tiwari et al. [1, 2]). Tiwari et al. [3] and Bryla et al. [4] reported that drip irrigation improved production and water use efficiency of faba bean in California using different levels of irrigation based on percentage of evapotranspiration. Ayars et al. [5] reported from their studies on subsurface drip irrigation and furrow irrigation in the presence of shallow saline ground water that yield of drip irrigated tomato were greater under drip irrigation than under furrow irrigation. Lamm and Trooien [6] reported that a successful application of subsurface drip irrigation for 10 year in Kansas, USA reduced the irrigation water use for corn by $35-55 \%$ compared with traditional forms of irrigation. Phene et al. [7] reported that subsurface drip irrigation improved water use efficiency (WUE) of tomato plants. Phene et al. [8] studied the distribution of roots under sweet corn as a function of drip placement and fertilization treatment. They reported differences between surface and subsurface drip irrigation on sweet corn rooting system in the top $45 \mathrm{~cm}$. High root length density was observed below $30 \mathrm{~cm}$ in the subsurface drip irrigation than in the surface drip.

\section{Materials and methods}

A field experiment has been established in 2002 to 2003. Squash plants (Cucurbita pepo) were grown in field plots on the College of Agricultural Research Station at Dirab (24 25 N, $46^{\circ} 34$ E), 40 km southwest of Riyadh, Saudi Arabia.. In brief, the soil was non-saline, non-sodic, calcareous and sandy texture. The irrigation systems layout is surface and subsurface drip irrigation while water quality was highly saline and moderately sodic. The natural clay deposits used in the experiment were collected from western region (Khulays) and central region (Dhurma and Rawdat areas) of Saudi Arabia. The experiment included also surface (S) and sub-surface (SS) drip irrigation methods.

Tomato (Lycopersicon esculentum L. cv. Bascal) seedlings were transplanted on 15 November 2003. Four irrigation levels $234 \mathrm{~mm}$ (T1), $330 \mathrm{~mm}$ (T2), $388.5 \mathrm{~mm}$ (T3), and $564.5 \mathrm{~mm}$ (T4) were applied over the entire season. The experiment has been laid out following the complete randomized block design with three replicates for each treatment. Each treatment consists of 7 drippers (2.8 $\mathrm{m}$ tubing) and the distance between two rows was about $1 \mathrm{~m}$. Three seedlings were transplanted at each dripper. Irrigation was commenced after transplantation and continued every other day until the end of experiment. Fertigation was used to deliver N-P-K soluble fertilizers to the plant root zone. 
Fruits were picked five times till the end of the season (April 17 $7^{\text {th }} 2004$ ) weighted, and the total yield was determined.

Twenty soil samples were collected before irrigation from the root zone area on a grid bases $(15 \mathrm{~cm}$ apart) around the dripper at the three growth stages. Water contents were determined by gravimetric method and alt distributions were assessed by measuring EC in 1:1, soil to water extract.

\section{Results and discussions}

Data in Table 1 showed that differences due to water regime, surface and subsurface drip irrigation and the interactions between water regime and irrigation methods were highly significant (at $1 \%$ level) for both tomato fruit yield and WUE. Differences in WUE and tomato fruit yields due to amendment rates and the interactions between amendment rates and water regime or irrigation methods were also significant (at $1 \%$ or $5 \%$ levels) whereas the interaction between amendment types and rates was not significant. Data also showed that differences due to amendment types and the interaction between water regime and amendments or the irrigation methods and amendments were not significant. These results reflect the positive effect of water regimes, surface and subsurface drip irrigation and amendment rates on tomato fruit yield and WUE.

The results are further elaborated in order to evaluate the effect of each treatment on tomato fruit yield and WUE. Effect of amendments types, irrigation regimes, irrigation methods and the amendment rates on tomato fruit yield and WUE are presented in Table 1 and graphically illustrated in Figures 1-4. It indicated that at high irrigation levels (non-stressed T4 and T3 treatments), fruit yield were high and decreased significantly at low irrigation levels (stressed, T2 and T1 treatments). The average yield increased by about $20.3 \%$ in the T4 treatment when compared with T3 treatment, whereas average yield decreased in the T2 and T1 treatments by about 72.0 and $123.0 \%$, respectively. However, WUE was highest at T3 and T1 treatments. The increase in the amount of irrigation water significantly affected the yield and WUE. The yield was the highest $\left(73.67\right.$ ton $\left.\mathrm{ha}^{-1}\right)$ at T4 $(564.5 \mathrm{~mm})$ and reduced to 32.89 ton $^{-1}$ in $\mathrm{T} 1$ (234 mm), a stress treatment.

The water production function (water applied vs. yield) (figures 1-2) showed that the subsurface drip irrigation has a better correlation and $r^{2}$ ranged from (0.98-.99), while the value of $\mathrm{r}^{2}$ for surface irrigation ranged between (0.17-0.78). This result is with full agreement with the result reported by Lamm and Trooien. The decrease in yield at low water application could be attributed to the unavailability of water and the possible accumulation of salts in root zone area as a result of using a high saline water (TDS $=3300 \mathrm{ppm})$, where no proper leaching took place. An increase in the irrigation amount did not show a definite trend in WUE. Results in Table 2 indicate that amendments type significantly affected the yield and WUE compared to the control. Dhurma clay deposit resulted in producing the highest average fruit yield and as well as WUE followed by Khulays and Rawdat. The yield increase was $12.92 \%, 2.48 \%$ and 
Table 1: Effect of clay deposits (type and rates), irrigation regimes and irrigation methods on Tomato yield (ton ha $\left.{ }^{-1}\right)$ and WUE $\left(\mathrm{kg} \mathrm{m}^{-3}\right)$.

\begin{tabular}{lcr}
\hline \multicolumn{1}{c}{ Treatments } & Yield (ton ha $\left.{ }^{-1}\right)$ & WUE ( kg \\
\hline \multicolumn{3}{c}{ Effect of clay deposits type } \\
Dhruma & $56.34 \mathrm{~A}$ & $14.64 \mathrm{~A}$ \\
Khulays & $51.13 \mathrm{~B}$ & $13.72 \mathrm{AB}$ \\
Rawdat & $50.49 \mathrm{~B}$ & $13.44 \mathrm{~B}$ \\
LSD $_{0.05}$ & 3.52 & 1.12 \\
& Effect of irrigation water regimes & \\
T1 & $32.89 \mathrm{D}$ & $14.04 \mathrm{~A}$ \\
T2 & $42.81 \mathrm{C}$ & $12.96 \mathrm{~B}$ \\
T3 & $61.24 \mathrm{~B}$ & $15.76 \mathrm{~A}$ \\
T4 & $73.67 \mathrm{~A}$ & $13.04 \mathrm{~B}$ \\
LSD $_{0.05}$ & 4.07 & 1.28
\end{tabular}

Effect of irrigation methods

Surface drip

Subsurface drip

$\operatorname{LSD}_{0.05}$
$50.76 \mathrm{~B}$

$54.55 \mathrm{~A}$

2.88
13.84

14.04

n.s.

Effect of amendment rates
Control
49.89 B
13.28 B
$1 \%$
$54.34 \mathrm{~A}$
$14.52 \mathrm{~A}$
$2 \%$
$53.71 \mathrm{~A}$
$14.08 \mathrm{AB}$
$\operatorname{LSD}_{0.05}$
3.53
1.12

* The same letter in each column represents no significant difference at $5 \%$ level. 
$1.2 \%$ for Dhruma, Khulays and Rawdat, respectively when compared with the control. The differences could be due to the clay deposit characteristics and the variation in $\mathrm{CaCO}_{3}$ content, ECe, CEC and the dominant clay minerals. Khulays deposit showed some desired characteristics such as low $\mathrm{CaCO}_{3}$, high $\mathrm{CEC}$ and the dominance of smectite clays, whereas it has relatively high original salinity which could be leached out of the root zone area before cultivation. Differences in tomato fruit yield due to irrigation methods were significant and the yield increase due to subsurface drip irrigation was about $7.47 \%$ over the surface drip irrigation. WUE did not show any significant difference between the two irrigation methods. It seems that subsurface drip irrigation creates more suitable conditions in the root zone area for the plant growth, which is in agreement with the result reported by Lamm and Trooien [5].

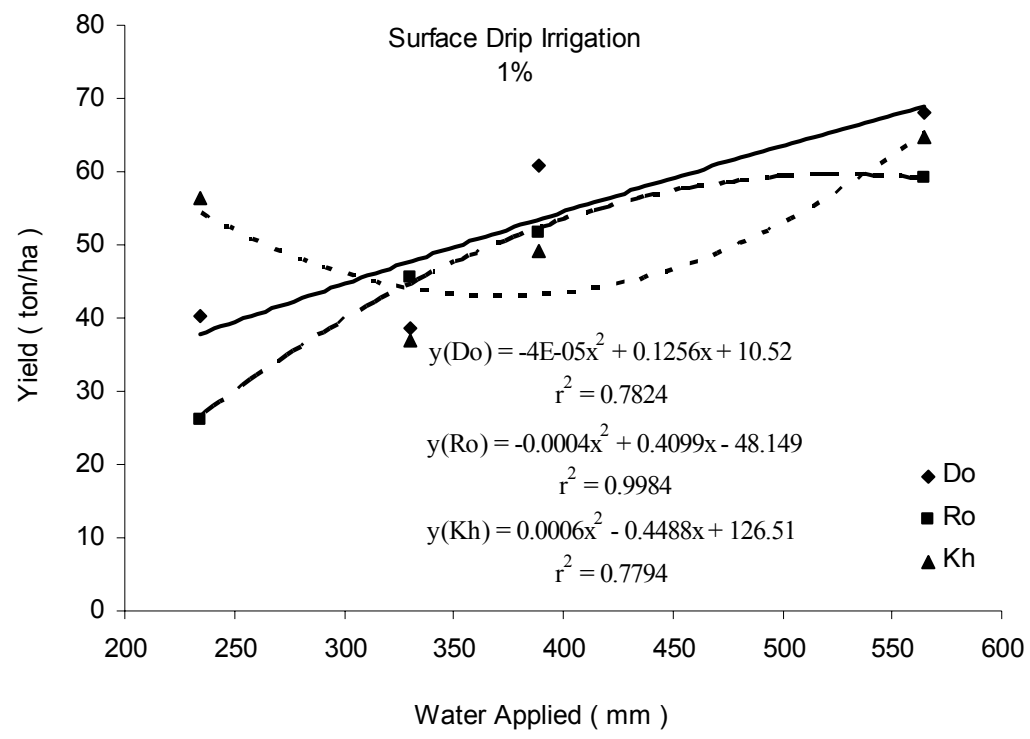

Figure 1: Relationship between tomato yield and water applied at surface drip irrigation under $1 \%$ rate of different natural deposits.

The amendment rates significantly affected tomato fruit yields under the experimental conditions. The average fruit yield was increased by $8.9 \%$ and $7.6 \%$ at 1 and $2 \%$ amendment rates when compared with control. Such increase in yield could be due to the improvement of sandy soil characteristics particularly the available water content and nutrient status. Also, differences in WUE due to amendment rates were significant. The application of clay deposits could have positive effects on soil texture, structure, swelling and increasing $\mathrm{CEC}$ and soil water retention, hence resulting in improved soil water contents in the tomato root zone.

Data of water and salt distributions in the root zone area for all treatments were graphically illustrated using Matlab software and data of selected treatments were presented in Figures 3 and 4. It indicated that water distributions 
show specific distribution patterns in the amended soil in both surface and subsurface drip irrigation. Such distribution pattern depends on the type and rate of amendment in the subsurface treatment. Water content was generally low (about 3-4\%) on the surface and increased gradually with depth without clear distribution trend (5-7\%). There was no clear difference between surface and subsurface drip irrigation in non amended soil where soil profile was not modified. Again, this trend could be due to water evaporation from the surface and hence decrease water content in the surface layer. The treated soils showed relatively high water content below $30 \mathrm{~cm}$ depth indicating deep percolation and partial losses of water below root zone. In amended soil water content was quite high at either surface or the subsurface drip irrigation treatment (Fig. 3) particularly in the amended subsurface layer ( soil water content $=10-12 \%$ in the soil treated with Khulays clays). It was clear that water seems to be stored in the treated layer with no or little percolation below $30 \mathrm{~cm}$ depth. The surface layer of the subsurface drip treatment was relatively dry and it seems to be uniform in dryness compared with the surface irrigation where dryness seems to be on the sides. Therefore, applications of clay deposits to sandy soils modifies the distribution of water content in the root zone area where water could be retained by clays applied to the subsurface layer. The desired characteristics of clay deposits could be reflected on the improvement of soil texture, structure, swelling, increasing CEC and soil water retention, hence resulted improved soil water contents in the tomato root zone. These data and conclusions agreed well with the results obtained for the previous crops as mentioned by (Al-Omran et al. [9]).

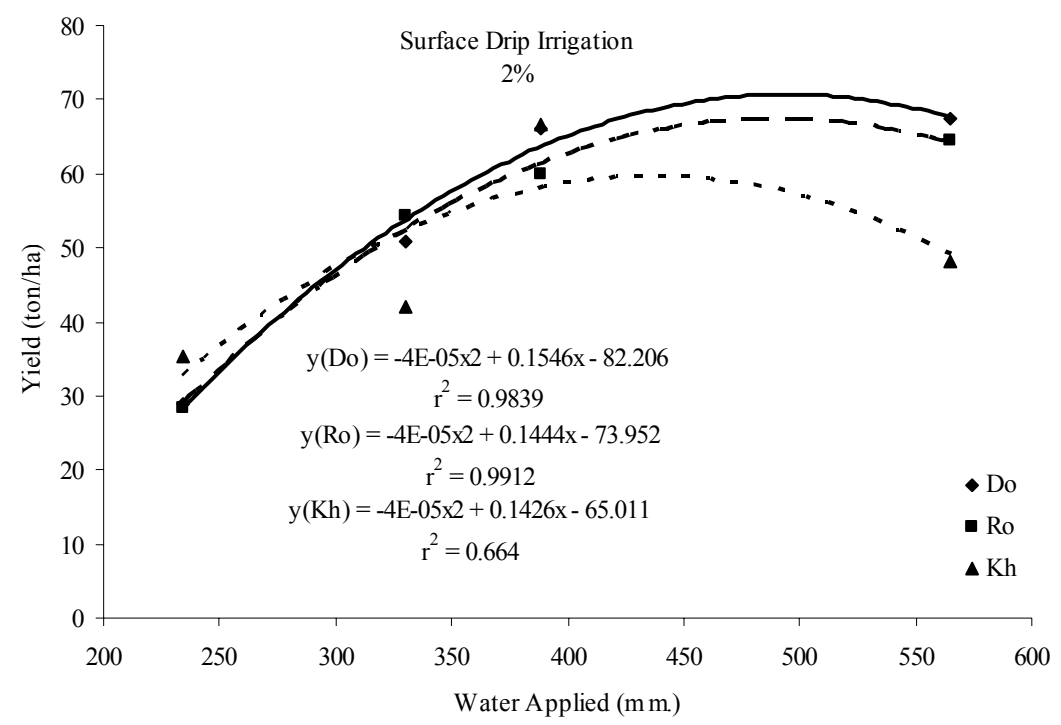

Figure 2: Relationship between tomato yield and water applied at surface drip irrigation under $2 \%$ rate of different natural deposits. 

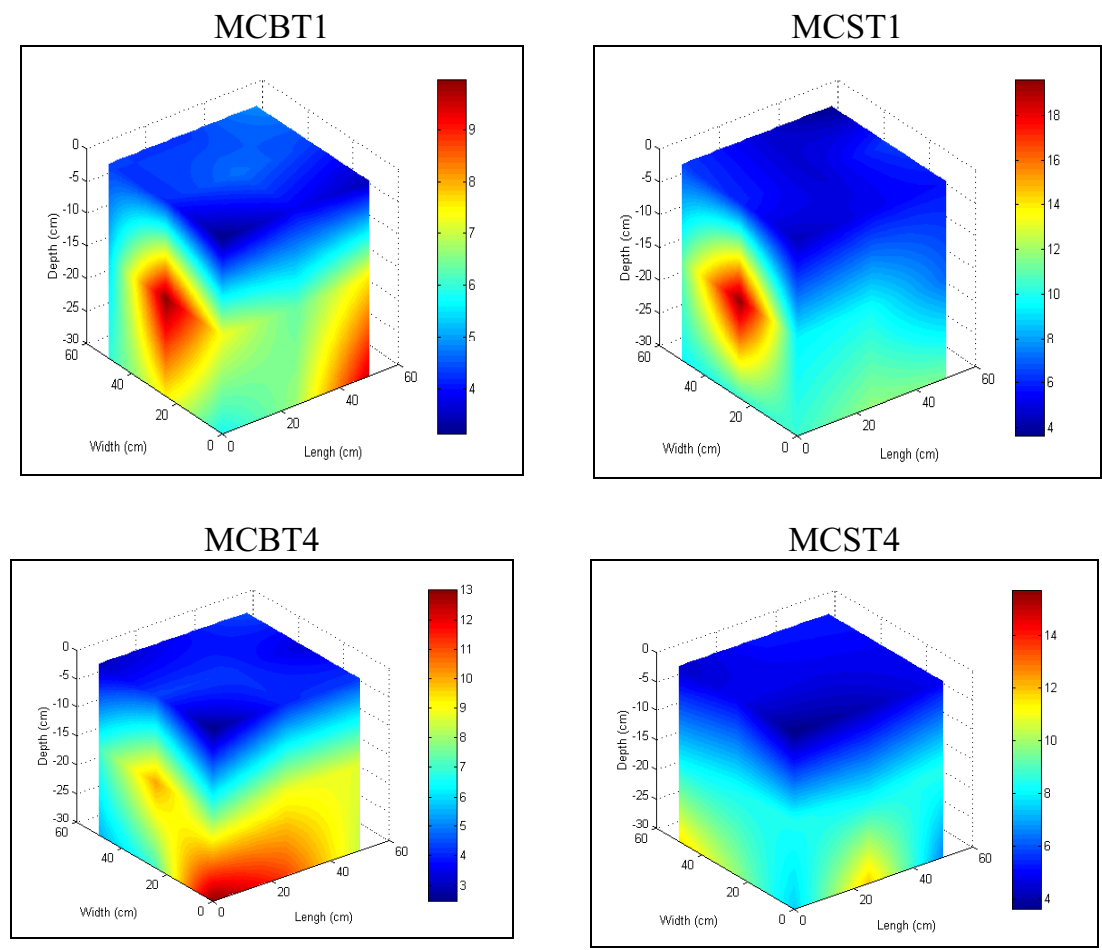

Figure 3: Water content distributions in the root zone area in surface and subsurface drip irrigation as affected by clay deposits. ( $\mathrm{MC}=$ moisture content, $\mathrm{B}=$ subsurface drip irr., $\mathrm{S}=$ surface drip irr., $\mathrm{T} 1=$ level 1 of water applied, T4 $=$ level 4 of water applied).

Soluble salt distributions (EC, dS/m) in the root zone area (Fig. 4) showed an adverse trend when compared with water distributions; it was high on the surface and decreased gradually with depth to the lowest values (at $15-30 \mathrm{~cm}$ depth). Amended soil with clay deposits (Rawdat deposit) indicated clear different trend particularly in the amended layer (about $20 \mathrm{~cm}$ depth). Salt concentration was relatively low in the amended layer while it accumulated on the surface in the subsurface drip irrigated soil and around the emitter in the surface drip irrigated soil. Salt accumulation appears to be reversibly related to water distribution in either surface or the subsurface drip. Again it appears that the subsurface amended layer have the lowest salt concentrations without clear differences when compared with the control. Therefore, increasing water content in the clay amended layer under subsurface drip seems to alleviate the harmful effect of salts and create more suitable conditions for root growth. 

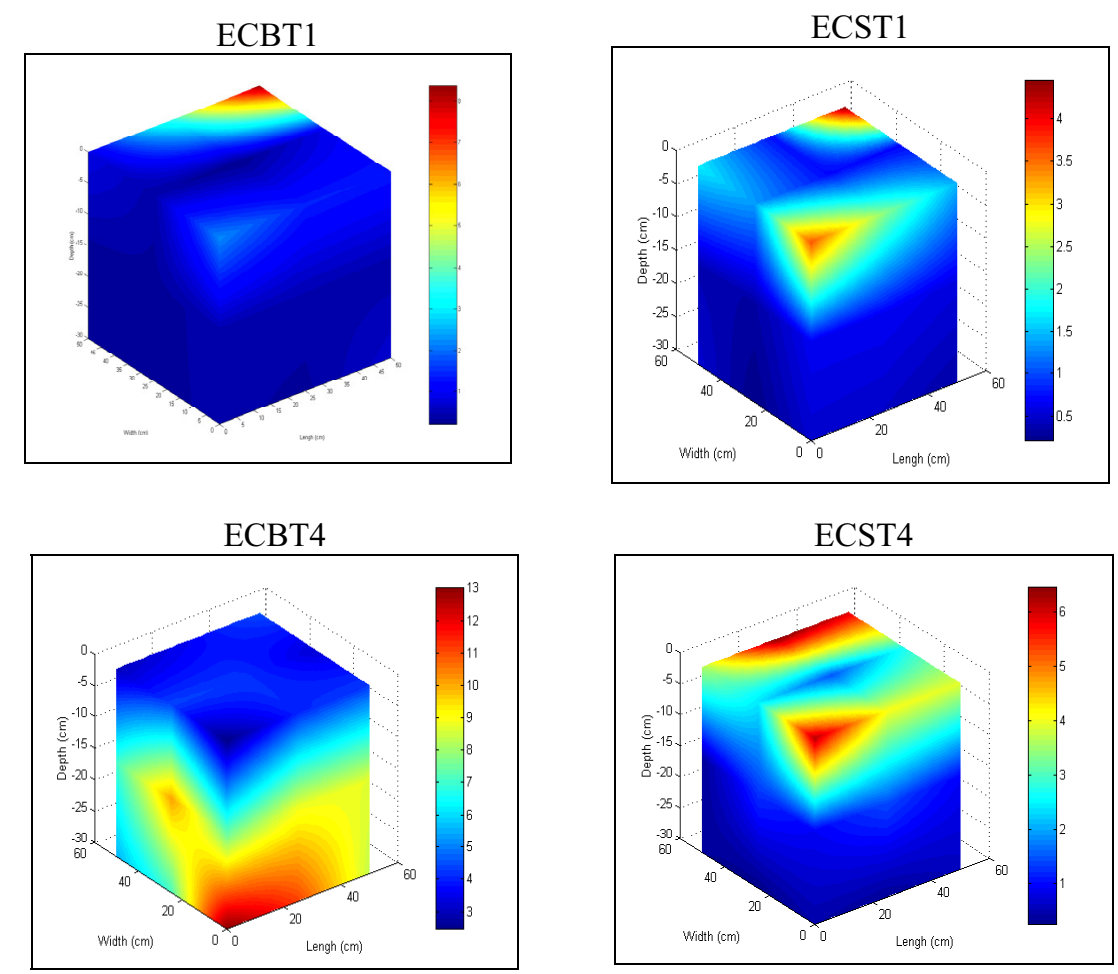

Figure 4: Salt distributions $(\mathrm{dS} / \mathrm{m})$ in the root zone area in surface and subsurface drip irrigation as affected by clay deposits. (EC = Electrical Conductivity, $\mathrm{B}=$ subsurface drip irr., $\mathrm{S}=$ surface drip irr., T1 = level 1 of water applied, T4 = level 4 of water applied).

\section{Conclusions}

Types of clay deposits significantly affected tomato yields and WUE compared with the control. The yield increase was $12.92 \%, 2.48 \%$ and $1.2 \%$ for Dhruma, Khulays and Rawdat, respectively when compared with the control. Clay amendment application as a subsurface layer to sandy calcareous soils increased water content, decrease soil salinity and improve the distribution of tomato roots in the treated layer.

\section{References}

[1] Tiwari, K. N., Mal, P. K., Singh, R. M. and Chattopadhyay, A. Response of Okra (Abelmoschus esculentus"L." Moench) to drip irrigation under mulch and non-mulch condition. Agric. Water Manage. 38: 91-102, 1998a. 
[2] Tiwari, K. N., Mal, P. K., Singh, R. M. and Chattopadhyay, A. Feasibility of drip irrigation under different soil covers in tomato. J. Agric. Eng., 35 (2): 41-49, 1998b.

[3] Tiwari, K. N., Singh, A. and Mal, P. K. Effect of drip irrigation on yield of cabbage (Brassica oleracea L. var. capitata) under mulch and non-mulch conditions. Agric. Water Manage., 58: 19-28, 2003.

[4] Bryla, D. R., Banuelos, G. S. and Mitchell, J. P. Water requirements of subsurface drip-irrigated faba bean in California. Irrig. Sci: 22 (1): 31-37, 2003.

[5] Ayars, J. Lschoneman, R. A., Dale, F., Meso, B. and Shouse, P. Managing subsurface drip irrigation in the presence of shallow ground water. Agric. Water Manage. 47: 243-264, 2001.

[6] Lamm, F.R. and Trooien, T.P. Subsurface drip irrigation for corn productivity: a review of 10 years of research in Kansas. Irrig. Sci: 22: (3-4), 195-200, 2003.

[7] Phene, C. J., Davis, K. R., Hutmacher, R. B. and McCormick, R. L. Advantages of subsurface drip irrigation for processing tomatoes. ActaHortic. 200: 101-113, 1987.

[8] Phene, C. J., Davis, K. R., Hutmacher, R. B., Bar-Yosef, B., Meek, D. W. and Misaki, J. Effect of high frequency surface and sub-surface drip irrigation on root distribution of sweet corn. Irrig. Sci., 12: 135-140, 1991.

[9] Al-Omran, A.M., Falatah, A.M., Sheta, A.S. and Al-Harbi, A.R. Effect of drip irrigation on squash (Cucurbita pepo) yield and water-use efficiency in sandy calcareous soils amended with clay deposits. Agric. Water Manage: 73: 43-55, 2005. 